\title{
APLIKASI TEKNOLOGI PEMBUATAN PUPUK ORGANIK PLUS UNTUK MENINGKATKAN PRODUKTIVITAS GAPOKTAN UMA DESA KABUPATEN KLUNGKUNG
}

\author{
I.G.R.M. Temaja ${ }^{1}$, G.N.A.S. Wirya ${ }^{2}$, dan N.L.G. Sumardani ${ }^{3}$
}

\begin{abstract}
ABSTRAK
Pelatihan singkat pembuatan pupuk organik plus dilaksanakan pada hari Kamis, 20 April 2017 bertempat di Simantri 376. Semua (32 orang) anggota Gapoktan Uma Desa berpartisipasi pada pelatihan ini. Tujuan pelatihan ini adalah untuk memberikan pengetahuan, pemahaman, dan ketrampilan pada kelompok petani peternak tentang peningkatan produktivitas melalui pemaanfaatan kotoran ternak sapi bali sebagai pupuk organik yang memiliki nilai ekonomis lebih tinggi. Metode pemecahan masalahnya adalah memberi teori dan praktek langsung tentang memformulasikan pupuk organik terfermentasi, Trichoderma pada media pembawa dan pupuk organik plus. Selama penyampaian teori dan praktek respon peserta sangat antusias, sehingga diskusi berlangsung aktif.
\end{abstract}

Kata kunci: pupuk organik, fermentasi, kotoran sapi, Trichoderma, transfer teknologi.

\begin{abstract}
The short course on organic fertilizer plus was held on Thursday, April 20, 2017 at Simantri 376. There are 32 members of Gapoktan Uma Desa participated in this program. The purpose of the short course is to provide knowledge, understanding and skill to members of Gapoktan about increasing productivity through the utilization of bali cattle dung as an organic fertilizer that has higher economic value. The problem solving method is to give theory and practice about formulating fermented organic fertilizer, Trichoderma on carrier media and organic fertilizer plus. During the delivery of theory and practice the participants' responses were very enthusiastic, so the discussion took place actively.
\end{abstract}

Keywords: organic fertilizer, fermentation, cattle dung, Trichoderma, technology transfer.

\section{PENDAhUluan}

Gabungan Kelompok Tani (Gapoktan) Uma Desa berkedudukan di Desa Takmung, Kecamatan Banjarangkan, Kabupaten Klungkung, Provinsi Bali. Gapokta Uma Desa memiliki 3 Kelompok Tani (Poktan) yaitu: Poktan Sedana Uma Desa dengan jumlah anggota 22 orang, Poktan Sri Uma Desa dengan jumlah anggota 20 orang, dan Poktan Ternak Uma Desa dengan jumlah anggota 22 orang. Anggota Gapoktan ini memiliki Rumah Tangga Miskin (RTM) lebih dari 35\%, sehingga memperoleh program pemberdayaan pedesaan dari pemerintah provinsi Bali melalui program Simantri (Sistem Pertanian Terintegrasi).

\footnotetext{
${ }^{1}$ Fakultas Pertanian, Universitas Udayana, raitemaja@unud.ac.id

${ }^{2}$ Fakultas Pertanian, Universitas Udayana

${ }^{3}$ Fakultas Peternakan, Universitas Udayana
} 
Masing-masing anggota Gapoktan rata-rata memiliki 2 ekor sapi. Total populasi sapi di Gapoktan Uma Desa ada 152 ekor, termasuk 21 ekor sapi program Simantri. Seekor sapi mampu menghasilkan kotoran padat dan cair $4 \mathrm{~kg} /$ hari. Setiap hari, lebih dari $600 \mathrm{~kg}$ limbah sapi yang dimiliki oleh Gapoktan Uma Desa. Ini melebihi dari kebutuhan pupuk organik anggotanya. Kotoran yang baru dihasilkan oleh sapi tidak dapat langsung dipakai sebagai pupuk tanaman, tetapi harus mengalami proses pengomposan (fermentasi) terlebih dahulu. Keterbatasan teknologi pengolahan limbah mengakibatkan limbah yang semestinya secara ekonomis memiliki nilai tambah, terbuang percuma.

Untuk memperoleh mutu pupuk organik yang baik diperlukan teknik pengolahan kotoran yang baik. Saat ini beberapa teknik pembuatan pupuk organik terfermentasi telah banyak dikaji. Penerapan teknologi maju ini akan diperoleh pupuk organik secara lebih cepat dengan mutu yang lebih baik. Diantara teknologi yang ditemukan adalah menggunakan mikroorganisme pendekomposis yang berfungsi sebagai dekomposer, sehingga mempercepat terbentuknya unsur hara yang tersedia untuk tanaman. Mikroorganisme pendekomposisi tersebut terdiri dari bakteri fotosintetik, bakteri asam laktat, actinomycetes, dan jamur fermentasi yang membantu mempercepat proses dekomposisi bahan organik kotoran sapi. Dengan kandungan mikroorganisme tersebut, akan memberikan keuntungan pada lahan pertanian memperbaiki sifat fisik, kimia dan biologi tanah (meningkatkan keragaman mikroorganisme menguntungkan), dan menyediakan unsur hara yang dibutuhkan oleh tanaman. Teknologi yang lain adalah memberikan tambahan agens pengendali penyakit tanaman (Trichoderma sp.) pada pupuk organik terfementasi, sehingga dapat membantu memproteksi tanaman dari gangguan-gangguan patogen. Trichoderma adalah jamur yang memiliki sifat antagonistik terhadap banyak patogen tular tanah, diantaranya jamur patogen dari genus Fusarium, Phytophthora, Rhizoctonia, Sclerotium, Rigidoporus, Verticillium dan Ganoderma, penyebab berbagai penyakit pada banyak jenis tanaman. Adanya Trichoderma sp. pada pupuk organik terfementasi, produk ini diberi nama pupuk organik plus.

Berdasarkan analisis diatas kegiatan ini dilakukan dalam rangka untuk memberikan pengetahuan, pemahaman, dan ketrampilan pada kelompok petani peternak tentang peningkatan produktivitas melalui pemaanfaatan kotoran ternak sapi bali sebagai pupuk organik yang memiliki nilai ekonomis lebih tinggi. Keterbatasan keterampilan dan teknologi mengakibatkan petani di subak ini tidak optimal menggali potensi penanganan limbah ternak untuk mendapatkan nilai tambah. Oleh sebab itu petani/peternak di Gapoktan Uma Desa membutuhkan pelatihan dalam memberikan pemahaman dan keterampilan untuk memanfaatkan secara optimal teknologi pembuatan pupuk organik plus. Kegiatan pelatihan dan penyuluhan yang akan dilakukan diharapkan dapat menciptakan iklim usaha tani yang lebih produktif, efisien dan optimal dalam berproduksi.

\section{METODE PELAKSANAAN}

Metode pemecahan masalah yang dilakukan adalah memberi materi pelatihan dan praktek langsung pembuatan pupuk organik plus bagi anggota Gapoktan Uma Desa sehingga mereka mampu meningkatkan keterampilan dan menguasai teknologi serta optimal menggali potensi penanganan limbah ternak untuk mendapatkan nilai tambah. Kegiatan telah dilaksanakan pada bulan April-Mei 2017 di Simantri 376 Desa Takmung, Kecamatan Banjarangkan, Kabupaten Klungkung, Provinsi Bali.

Pupuk organik plus dibuat dengan memformulasikan pupuk organik terfermentasi dengan biakan massal Trichoderma pada media pembawa. Pupuk organik terfermentasi dibuat dari campuran bahan-bahan dengan masing-masing komposisi volumenya seperti pada Tabel 2.1.

VOLUME 17 NOMOR 1, JANUARI 2018 | 46 
Aplikasi Teknologi Pembuatan Pupuk Organik Plus Untuk Meningkatkan Produktivitas Gapoktan Uma Desa Kabupaten Klungkung

Tabel 2.1. Bahan dan komposisi volume masing-masing bahan untuk pembuatan pupuk organik terfermentasi

\begin{tabular}{lc}
\hline Bahan & Jumlah satuan \\
\hline Dedak & 20 liter \\
Pupuk kandang & 20 liter \\
Sekam padi & 20 liter \\
Arang sekam & 20 liter \\
Tanah & 20 liter \\
Tepung tulang & 1 liter \\
Ampas minyak kelapa & 1 liter \\
Starter (EM4) & $50 \mathrm{ml}$ \\
Air gula & Gula pasir $300 \mathrm{~g} / 5$ liter air \\
\hline
\end{tabular}

Cara pembuatan pupuk organik terfermentasi adalah dengan mencampurkan dedak, pupuk kandang, sekam, arang sekam, tanah, tepung tulang dan ampas minyak kelapa; ditambahkan larutkan EM 4 dalam cairan gula dengan menyiramkan larutan EM 4 sambil diaduk-aduk hingga campuran bahan organik basah secara merata (bila adonan dikepal dengan tangan, air tidak menetes dan bila kepalan dilepas adonan akan mekar/kadar air $\pm 30 \%$ ). Adonan dibuat gundukan di atas lantai (kering), kemudian tutup dengan karung goni atau terpal plastik selama 14 hari. Adonan setiap hari dibolak balik untuk mengurangi panas yang timbul.

Biakan massal Trichoderma pada media pembawa disiapkan dari campuran bahan-bahan dengan komposisi volumenya seperti pada Tabel 2.2.

Tabel 2.2. Bahan dan jumlah satuan masing-masing bahan untuk pembuatan biakan massal Trichoderma

\begin{tabular}{lc}
\hline Bahan & Jumlah satuan \\
\hline Sekam & $2 \mathrm{~kg}$ \\
Dedak & $1 \mathrm{~kg}$ \\
Air akuades & $0,5 \mathrm{~L}$ \\
Air sumur & $10 \mathrm{~L}$ \\
Isolat / starter Trichoderma sp., & 1 test tube \\
Alkohol $90 \%$ & \\
\hline
\end{tabular}

Cara pembuatan biakan massal Trichoderma pada media pembawa adalah dengan mencampurkan sekam dan dedak hingga merata, ditambahkan air hingga bahan memal. Memasukan behan kedalam kantong plestik kira2 $1 \mathrm{~kg} /$ kantong dan ditutup dengan kancing staples. Menanak bahan selama 3 jam dimulai dari mendidihnya air, tiriskan hingga dingin. Mencampurkan starter Trichoderma sp., ke media hingga rata. Menuangkan bahan tersebut diatas meja denga alas plastik diatasnya, diratakan hingga ketebalan $2 \mathrm{~cm}$ dan tutuplah denga plastik yang steril. Inkubasi 5 sampai 7 hari biakan massal Trichoderma pada media pembawa sudah siap dipakai, yang ditandai dengan warna kebiru-biruan pada media.

Formulasi pupuk organik plus dibuat dengan mencampurkan merata $500 \mathrm{~g}$ biakan massal Trichoderma kedalam $50 \mathrm{~kg}$ pupuk terfermentasi yang sudah jadi. Memasukan campuran ke dalam karung plastik. Inkubasi campuran 3 hari dan kemudian siap dimasukkan ke dalam kemasan. 


\section{HASIL DAN PEMBAHASAN}

\subsection{Pembuatan pupuk organik plus}

Pupuk organik plus dibuat dengan memformulasikan pupuk organik terfermentasi dengan biakan massal Trichoderma pada media pembawa, sehingga pupuk organik hasil fermentasi yang mengandung unsur hara esensial untuk menutrisi tanaman dilengkapi dengan Trichoderma sp. untuk melindungi tanaman dari berbagai macam penyakit tular tanah seperti: Rhizoctonia sp., Pythium sp., Sclerotium sp., Fusarium sp., Phytoptora sp., Ganoderma, Lentinus sp., Botrytis sp., Gloesporium sp., Rigidoporus sp., Diploda sp., Antraknosa, Jamur upas, dan embun tepung.

Sosialisasi materi pembuatan pupuk organik plus ini dilakukan melalui kegiatan penyuluhan dan pelatihan. Pada sosialisasi ini tim pelaksana program pengabdian memberikan pengetahuan teoritis kepada petani padi tentang inovasi pembuatan pupuk organik plus, manfaat pupuk organik terfermentasi dan Trichoderma. Materi diberikan oleh ketua tim pengabdi (Prof. Dr. Ir. I Gede Rai Maya Temaja, MP.). Penyuluhan dilaksanakan pada hari Kamis, 20 April 2017 bertempat di Simantri 376, dihadiri oleh semua anggota Gapoktan Uma Desa. Peserta dalam kegiatan ini sebanyak 32 orang anggota Gapoktan Uma Desa dan juga dihadiri 2 orang petani dari luar gapoktan yang tertarik dengan pembuatan pupuk organik plus (Gambar 3.1.). Selama penyampaian materi penyuluhan dan pelatihan oleh tim pelaksana program, petani peserta sangat tertarik, sehingga tanya jawab dan diskusi berlangsung aktif.
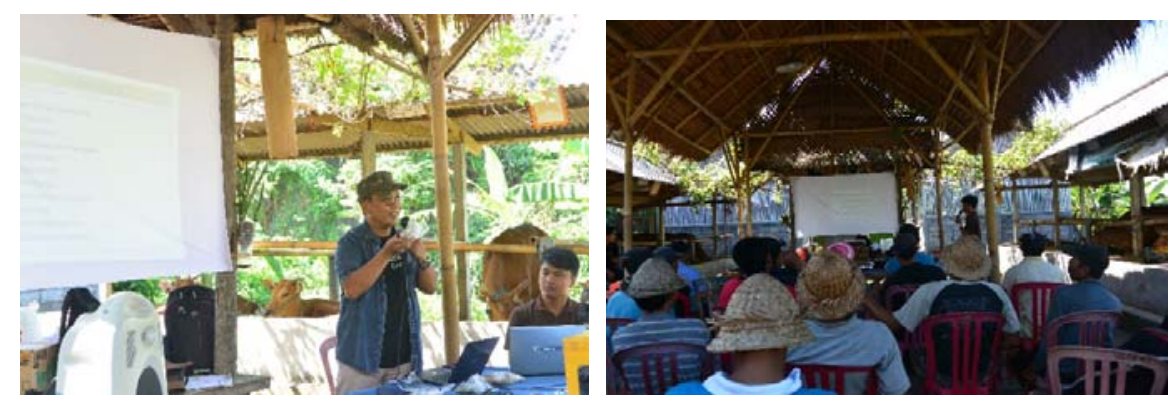

Gambar 3.1. Penyampaian materi pembuatan pupuk organik plus

Merintis kemandirian kelompok dalam pengadaan bahan-bahan yang diperlukan dalam produksi, tim pelaksana program memberikan sumbangan perlengakapan mini laboratorium untuk perbanyakan jamur Trichoderma antara lain entkas, tabung reaksi, erlenmeyer, petridish, gelas ukur dan panci sterilisasi (Gambar 3.2.). Kegiatan dilanjutkan dengan praktek pembuatan media tumbuh jamur Trichoderma yaitu media PDA; sterilisasi; penumbuhan jamur Trichoderma pada media PDA; dan pemindahan/penumbuhan jamur Trichoderma pada beras dan jagung (Gambar 3.3.).

Pembuatan pupuk organik terfermentasi sebagai komponen utama pupuk organik plus dilaksanakan pada hari Minggu 23 April 2017. Pupuk organik terfermentasi dibuat dari campuran bahan-bahan: dedak, pupuk kandang, sekam padi, arang sekam, tanah, tepung tulang, ampas minyak kelapa, starter (EM4), dan air gula. Campuran bahan-bahan tersebut dibuat gundukan diatas lantai kering, kemudian tutup dengan terpal plastik selama 14 hari. Selama masa inkubasi tersebut, secara periodik dilakukan pemantauan suhu gundukan, membuka tutup terpal plastik seekitar 10 menit dan campuran dibolak balik untuk mengurangi panasnya (Gambar 3.4.). Mendapatkan produk pupuk organik terfermentasi yang hampir seragam, pupuk yang sudah jadi diayak untuk memisahkan sampah dan agregat berukuran besar (Gambar 3.5.). 

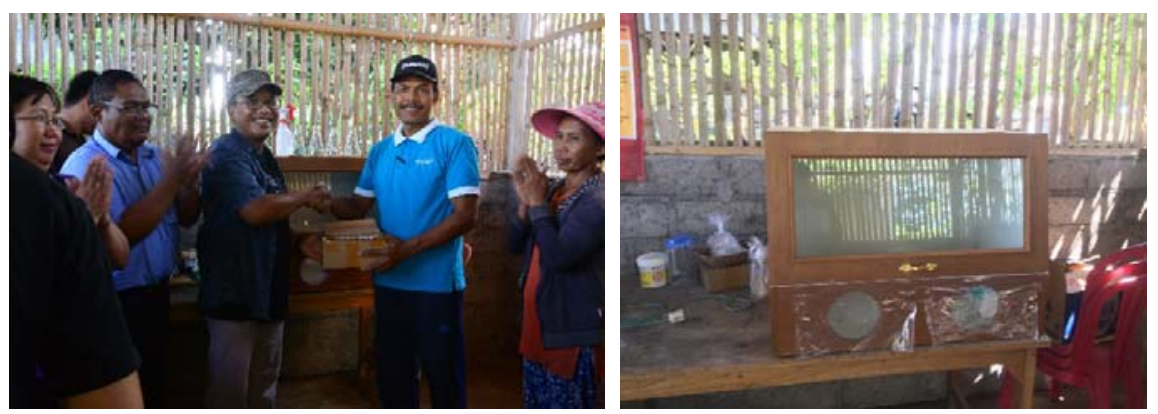

Gambar 3.2. Pemberian sumbangan perlengakapan mini laboratorium (entkas, tabung reaksi, erlenmeyer, petridish, gelas ukur dan panci sterilisasi)
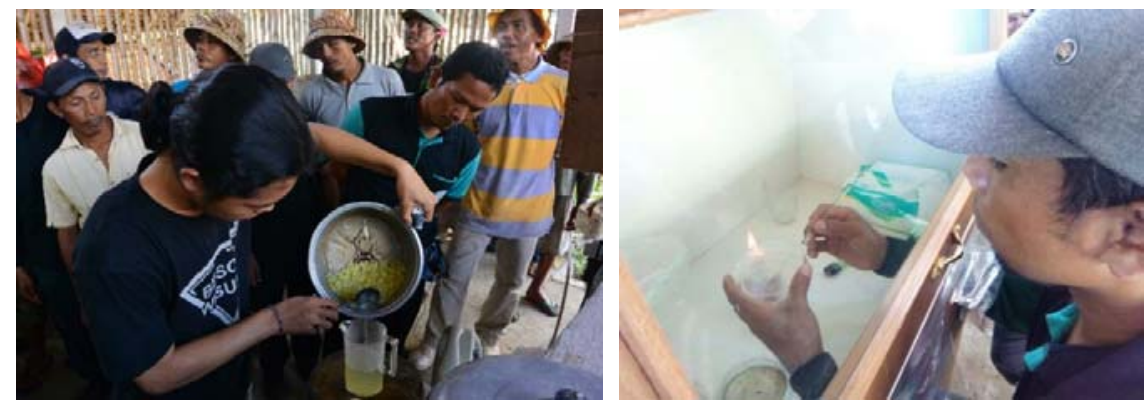

Gambar 3.3. Praktek pembuatan media PDA, sterilisasi dan penumbuhan Trichoderma
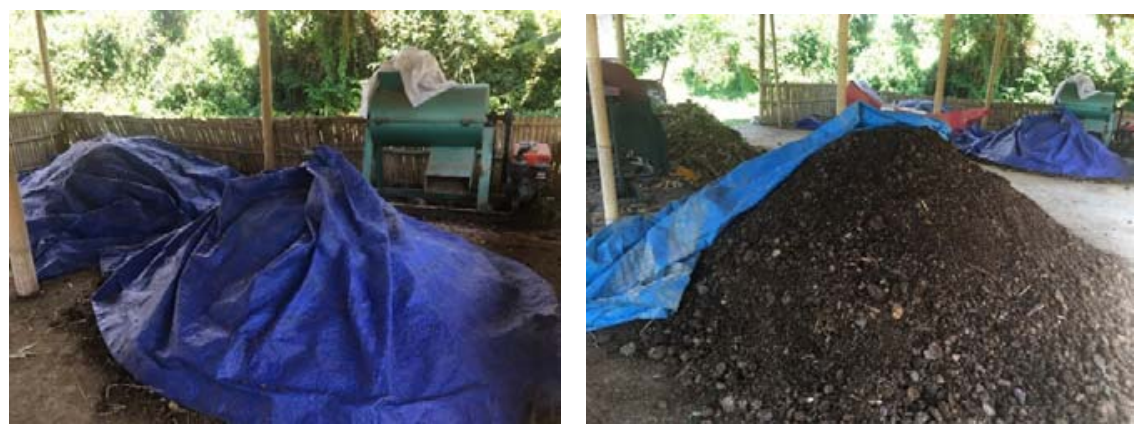

Gambar 3.4. Campuran bahan pupuk organik terfermentasi dibuat gundukan diatas lantai kering, dan ditutup dengan terpal plastik selama 14 hari 

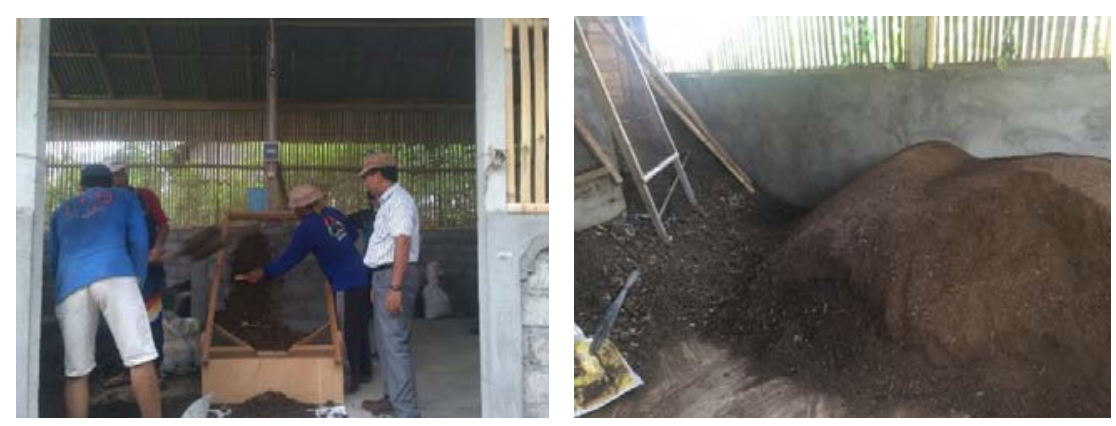

Gambar 3.5. Pupuk organik terfermentasi yang sudah jadi diayak untuk memisahkan sampah dan agregat berukuran besar

Praktek pembuatan pupuk organik plus tahap berikutnya dilakukan setelah jamur Trichoderma pada beras dan jagung disimpan selama 2 minggu. Lima puluh kilogram pupuk organik terfermentasi yang sudah jadi dicampurkan dengan 500 g biang Trichoderma pada media pembawa, dibasahi hingga memal, dimasukan ke dalam karung plastik, dan dibiarkan/diinkubasi 3 hari (Gambar 3.6.).
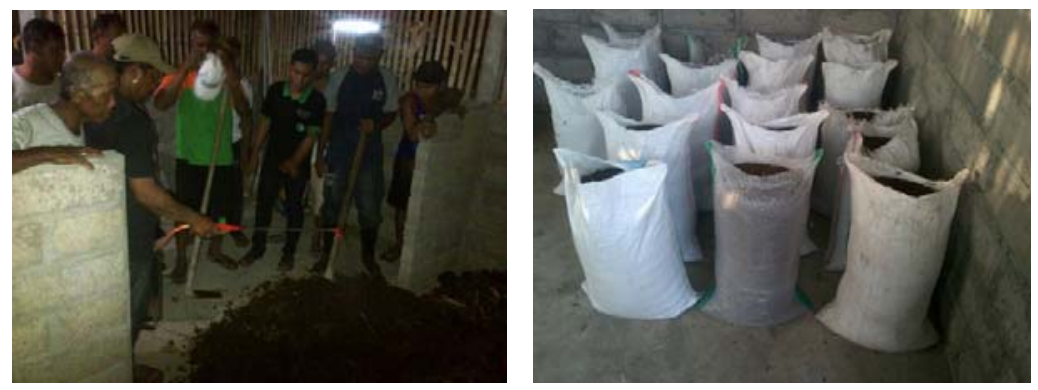

Gambar 3.6. Pupuk organik terfermentasi dicampurkan dengan biang Trichoderma pada media pembawa, dibasahi hingga memal, dimasukan ke dalam karung plastik

\subsection{Pengemasan produk}

Produk pupuk organik plus yang diproduksi di Gapoktan Uma Desa disepakati dengan nama dagang "TRIUMA376" yang dikemas dalam kemasan $4 \mathrm{~kg}$ dan $20 \mathrm{~kg}$ (Gambar 3.7). Kemasan 4 $\mathrm{kg}$ berupa kantong plastik dan kemasan $20 \mathrm{~kg}$ adalah karung plastik. Kemasan didesain dan mencantumkan informasi produk seperti nama dagang, komposisi, manfaat, aturan pakai, dosis, berat dan lembaga produsen. 

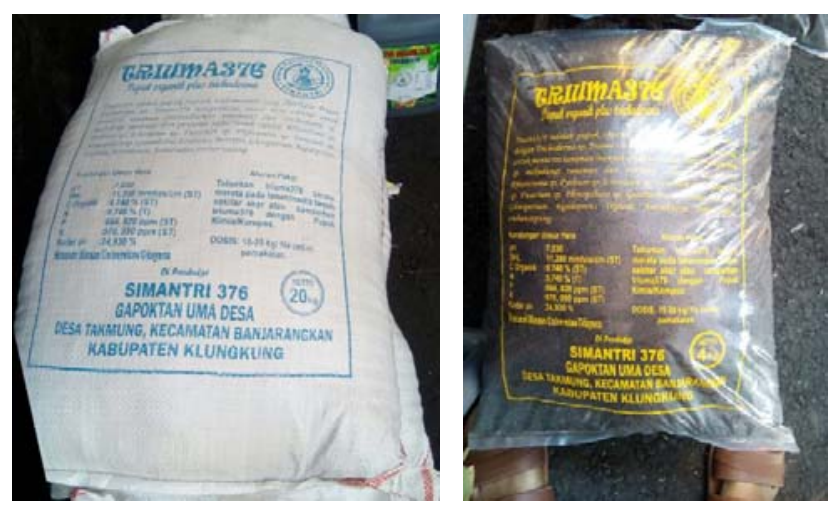

Gambar 3.7. Pupuk organik plus dalam kemasan $20 \mathrm{~kg}$ dan $4 \mathrm{~kg}$

\section{KESIMPULAN DAN SARAN}

Berdasarkan hasil evaluasi terhadap kegiatan pengabdian yang telah dilakukan, dapat disimpulkan bahwa anggota Gabungan Kelompok Tani (Gapoktan) Uma Desa berkedudukan di Desa Takmung, Kecamatan Banjarangkan, Kabupaten Klungkung, Provinsi Bali, memberikan respon yang positif terhadap pelaksanaan pengabdian pembuatan pupuk organik plus, ditunjukkan oleh antusiasme kelompok simantri untuk berperan aktif dalam kegiatan sehingga program berjalan efektif dan produktif, serta menjadi media mereka dalam peningkatan pengetahuan dan keterampilan berwirausaha. Dengan adanya program pengabdian IbM ini Gapoktan Uma Desa memperoleh nilai tambah dari produk baru yang dihasilkan yaitu pupuk organik plus "TRIUMA376".

Permintaan produk yang meningkat akan berakibat pada ketersediaan sarana produksi atau bahan baku. Mengantisipasi hal tersebut, untuk kontinyuitas produksi pengurus Gapoktan mencarikan solusi dari pengadaan bahan baku, misalnya dengan membeli limbah ternak sapi di luar anggota Gapoktan.

\section{UCAPAN TERIMAKASIH}

Pengabdian ini dibiayai oleh Direktorat Riset dan Pengabdian Masyarakat Direktorat Jendral Penguatan Riset dan Pengembangan Kementerian Riset, Teknologi, dan Pendidikan Tinggi melalui skema pengabdian IbM dengan Kontrak Pengabdian kepada Masyarakat Nomor: 416.9/UN.14.4.A/PM/2017, tanggal 30 Maret 2017.

\section{DAFTAR PUSTAKA}

Admiraldi, Y. 2011. Kajian Proses Produksi dan Pengendalian Mutu Proses Pengemasan Pupuk Urea di PT Pupuk Kujang. Skripsi. Institut Pertanian Bogor.

Affandi. 2008. Pemanfaatan urine sapi yang difermentasi sebagai nutrisi tanaman. http://affandi21.xanga.com (diakses 11 Maret 2009)

Hadinata, I. 2008. Membuat mikroorganisme lokal (MOL). Dewi Sri PM Himatek. Jakarta. http://ivanhandinata@yahoo.com (diakses 11 Maret 2009)

Hadisuwito, S. 2007. Membuat Pupuk Kompos Cair. Agromedia Pustaka. Jakarta.

Kotler, P. 1997. Manajemen Pemasaran: Analisis, Perencanaan, Implementasi dan Kontrol, (Terjemahan), Airlangga, Jakarta 
Takahashi, H. 2001. Production of Bokashi Fertilizer and Its Effects on Vegetable Growing. In Fujimoto, A and Abdullah, K. (ed.) Highlang Vegetable Cultivation in Indonesia. A Multi Disciplinary Study toward Eco-Eco Farming. World Planning, 295-304.

Willyan D., N. K. Suwardi, L. B. Salman. 2003. Pengaruh imbangan kotoran sapi perah dan serbuk gergaji terhadap kualitas kompos. Laporan Penelitian. Dibiayai Oleh Dana DIK Universitas Padjadjaran Tahun Anggaran 2003 